\title{
Non-Conventional Pain Management for Sickle Cell Disease
}

\author{
Hassan Al-J afar ${ }^{1 *}$, Aziz Al-Feeli² and Abdulla \\ Alozairi ${ }^{3}$ \\ ${ }^{1}$ Department of Hematologist, Amiri Hospital, Kuwait \\ ${ }^{2}$ Consultant Physiatrist, Amiri Hospital, Kuwait \\ ${ }^{3}$ Consultant Psychiatrist, Kuwait University, Kuwait \\ *Corresponding author: Hassan Al-J afar, Department \\ of Hematologist, Amiri Hospital, Kuwait
}

Received: May 11, 2017; Accepted: J une 12, 2017; Published: July 06, 2017

\begin{abstract}
Sickle cell disease is a congenital blood disorder affecting hemoglobin molecule. It leads to a rigid, sickle like shape red blood cell. Most people with sickle cell disease have severe painful episodes called vaso-occlusive crises. However, the frequency, severity, and duration of these crises vary tremendously. The pain is classified into two types, nociception pain which is intact peripheral or central nervous system and neuropathic pain which is initiated by dysfunction of the peripheral or central nervous system. Despite the pain being the most common complication of sickle cell disease, there is a lack of novel pain treatments. Pain killers including opioid have continued to be the main stay of therapy over the past several decades. A non-conventional treatments for pain were applied effectively to avoid the serious systemic side effects of the pharmaceutical pain killers.
\end{abstract}

\section{Introduction}

Sickle cell disease (SCD) affects hemoglobin, the molecule in red blood cells that delivers oxygen to cells. This disorder has atypical hemoglobin molecule called hemoglobin S, which leads to a rigid, sickle-like shape red blood cell under certain circumstances. Problems in SCD typically begin around 5 to 6 months of age. Long term pain develops as people get older [1]. SCD may lead to various acute and chronic complications, several of which have a high mortality rate [2]. Most people with SCD have intensely painful episodes called vaso-occlusive crises. However, the frequency, severity, and duration of these crises vary tremendously. Painful crises complications are treated symptomatically with pain killer medications at regular intervals until the crisis settle down. The vaso-occlusive crisis is caused by sickle-shaped red blood cells that obstruct capillaries and restrict blood flow to an organs resulting in ischemia, pain, and often organ damage. The frequency, severity, and duration of these crises vary considerably [3]. Pain is the hallmark of SCD and the acute sickle cell painful episode is the most common cause of more than $90 \%$ of hospital admissions among adult patients who have SCD [4]. Effective management of sickle cell pain is variable and complicated [5]. Major prerequisites for an effective and rational management of sickle cell pain depend on the patient, the pathophysiology of the disease, the pharmacology of analgesics, and the attitude of the health care provider. Sickle cell pain is also strongly affected by psychological, social, cultural, and spiritual factors. It is, however, consequent to tissue damage generated by the sickling process and occlusion of the micro-vasculature [6].

Current research in characterizing pain in SCD patients indicates that both acute and chronic pain are prevalent among the adult patients, while infants and children mostly suffer from acute pain $[7,8]$. The shift from acute to chronic pain may therefore occur during the transition from childhood to adolescence. Young children with a median age of 3.8 years (range 0.3-7.6 years) exhibited less frequent pain. In another, study 100 young subjects, about $40 \%$ of children and adolescents in the age range of 8-18 years reported chronic pain with another $40 \%$ exhibiting episodic pain, and the remainder had no pain. Though the pain intensity and quality of life were comparable among the young patients with chronic and episodic pain, the patients with chronic pain suffered from greater functional disability, depression and hospital admissions compared to the episodic pain group [9]. The adult patients recruited in the Pain in Sickle Cell Epidemiology Study (Pisces) reported chronic SCD pain on 54.5\% [8]. Opioids have remained the major strategy to treat acute sickle pain, while chronic pain is managed with the combination of Non-Steroidal Anti-Inflammatory Drugs (NSAIDs), opioids, anti-depressants, and anticonvulsant medications [10]. However, to date no satisfactory therapy exists [11].

\section{Types of pain}

Nociception Pain is the more common type of pain in SCD. It is the process by which intense thermal, mechanical or chemical stimuli are detected by a sub population of peripheral nerve fibers, called nociceptors [12]. Nociception pain could happen due to vision, hearing, tasting, and feelings without nerve damage. The signals, when these nociceptors are activated, must be transduced and transmitted to the spine and brain where signals are modified before they ultimately understood [13]. Interaction of inflammatory mediators or nociceptive pain in SCD involves four major pathophysiological processes: transduction, transmission, modulation, and perception [14]. Pain transduction refers to the processes by which tissuedamaging stimuli activate nerve endings. Pain transmission refers to the message carried from the site of tissue injury to the brain. Pain modulation occurs when neurons in the thalamus and brain stem send signals down to the dorsal horn of the spinal cord. Pain perception is the sum of complex activities in the Central Nervous System (CNS) that may shape the character and intensity of pain [15]. Nociceptive somatic pain is the most common type of pain in patients with cancer and bone metastases. The widespread use of bisphosphonates has resulted in improved analgesia and a significant reduction of skeletal complications in patients with malignant bone pain [16]. Nociceptive visceral pain is mediated by discrete nociceptors in the cardiovascular, 
respiratory, gastrointestinal, and genitourinary systems. It is usually described as deep, squeezing, or colicky and is commonly referred to cutaneous sites, which may be tender. Recent experimental data in animals suggests that kappa-opioid receptor agonists are uniquely efficacious in the treatment of nociception visceral pain $[17,18]$.

Neuropathic pain is defined as pain initiated by damage or dysfunction of the peripheral or Central Nervous System [19]. This is in contrary to inflammatory or nociceptive pain where tissue damage not nerve damage causes the pain [20]. Pain is a frequent complaint of people living with SCD. Nationwide epidemiological survey data indicate that over half of sickle cell patients, they have 1-2 episodes annually. One percent of patients have more than 10 episodes [21]. Hospital admissions for acute painful episodes have been reported to be a predictor of prognosis. Moreover, half of those hospital admissions are readmitted within 1 month after discharge [22]. A more recent study followed diary recordings of SCD patients for up to 6 months and found that $55 \%$ of patients with SCD reported pain on more than half of the diary days [23]. Risk for mortality in adults with SCD increases for patients with increased rates of painful episodes [20]. Amanda, et al. found that almost 40\% of SCD study population had evidence of neuropathic pain [19]. Although the underlying pathobiology of SCD pain is not well known $[24,25]$. Neuropathic pain is shown to be associated with higher pain intensity and longer duration, it is harder to treat, and is more refractory to conventional analgesics [26]. Wilke, et al. found only $14 \%$ of their SCD study population reported taking an adjuvant drug that could treat neuropathic pain [27]. The infrequent use of neuropathic pain drugs could be because patients are not systematically screened for the presence of neuropathic pain. Appropriate screening using validated tools can identify patients with SCD that may benefit from existing neuropathic pain therapies [28].

\section{Non-conventional management approaches}

Psychotherapy treatment: Refers to therapeutic interaction or treatment between a trained professional and patient [27]. These primarily relieve symptoms by exploring the patient's underlying psychological conflicts and emotional disturbances. The psychotherapy focused on mechanisms for coping with stress and resolving emotional problems [29]. In SCD, the impact of genetic and environmental effects can be estimated in the psychological disorders such as the major depression or the individual symptoms like sadness or insomnia. Thus, a number of pain treatments focusing on psychosocial management of episodic painful vaso-occlusive crises and on emphasizing the proper manipulation of the environmental conditions, behaviors, or cognitions to effect change in response to pain. Change is believed to arise from psycho, social, supportive and validating therapeutic environment, in the traditional psychoanalytic approaches or in conflict model of psychopathology and behavioral disorder [30].

Relaxing exercise: Therapy is recommended as an effective treatment for relieving pain with lower back pain by most clinical guidelines [31]. The relaxation response is perhaps one of the most important skills used to gain control over the body. In addition, research on the relaxation response has shown that relaxation can: increase energy, decrease fatigue. It can increase motivation, productivity, and improve decision-making ability. The relaxation response lowers stress hormone levels and lowers blood pressure. It defined as the personal ability to make body release chemicals and brain signals that make muscles and organs slow down and increases blood flow to the brain. There are many ways of achieving the relaxation response. Some of these techniques are called Progressive Muscle Relaxation, Visual Imagery, Deep Breathing, Meditation, Hypnosis, Yoga, and Biofeedback. To date, there is no data supporting the idea that one method is better than any other. What does matter is the willingness to use a particular technique for own health and the ability to gain relaxation through that method [32].

Transcutaneous electrical nerve stimulation (TENS): Has been clinically used for over three decades; the mechanisms by which analgesia is produced are only recently being described [33]. Gate control theory is the most common theory used to support the effect of inhibiting pain by TENS. Pain is reduced when the area is rubbed or stimulated due to activation of non-nociceptive fibers inhibiting the nociceptive response in the dorsal horn of the spinal cord. In TENS, non-nociceptive fibers are selectively stimulated with electrodes in order to produce this effect and thereby inhibit pain [34]. One randomized double-blinded study showed that TENS intervention in female patients with salpingitis, ovarian cyst, dysmenorrhea, reduced pain, anxiety, heart rate, nausea, and arteriolar vasoconstriction with an improvement of overall patient satisfaction [35]. The effect of TENS producing pain relief was further supported in another study in which patients suffering from acute posttraumatic hip pain felt less pain and anxiety with TENS intervention [36]. These observations suggest that TENS could be an effective and fast-acting pain treatment with applications within paramedic practice [37]. TENS has been used in a variety of acute and chronic painful conditions, but has not been studied in SCD pain crises yet which could be a research for the non-nociceptive fibers [38].

Placebo treatment: Placebo treatment is a simulated or otherwise medically ineffectual treatment for a disease or other medical condition intended to deceive the recipient. A person given such an ineffectual treatment will often have a perceived or actual improvement in their condition, a phenomenon commonly called the placebo effect or placebo response [39]. Several different elements contribute to the effect, and the methods of placebo administration may be as important as the administration the drug itself [40]. Common placebos include inert tablets like sugar pills, vehicle infusions [41] and other procedures based on false information [42]. It has also been shown that use of therapies about which patients are unaware is less effective than using ones that patients are informed about. Placebo effects are the subject of scientific research aiming to understand underlying mechanisms [43]. Brain imaging techniques done by Emeran Mayer, Johanna Jarco and Matt Lieberman showed that placebo can have real, measurable effects on physiological changes in the brain [44]. Placebos can produce some objective physiological changes, such as changes in heart rate, blood pressure, and chemical activity in the brain, in cases involving pain, depression, anxiety, fatigue [45]. Ernst and Resch also attempted to distinguish between the "true" and "perceived" placebo effect, as they argued that some of the effects attributed to the placebo effect could be due to other unknown factors [46].

Vibration therapy: Vibration therapy is a mechanical stimulus 
characterized by an oscillatory motion. The biomechanical variables that determine its intensity are the frequency and amplitude. The extent of the oscillatory motion determines the amplitude (peak to peak displacement, in $\mathrm{mm}$ ) of the vibration. The repetition rate of the cycles of oscillation determines the frequency of the vibration (measured in $\mathrm{Hz}$ ) [47]. Recent work has suggested that low amplitude, low frequency mechanical stimulation of the human body is safe and effective way to exercise and relieve musculoskeletal pain [48] Vibration therapy works in two ways. First, the gentle vibrations help stimulate muscles and ligaments to increase blood circulation. Second, the vibrations serve as a sensory distraction, disrupting pain signals that are constantly traveling from the body to the brain and replacing them with gentle, massaging sensations [49] Best of all, with vibration therapy, there is no feeling of electric shock commonly associated with TENS units [50]. Vibration therapy and circulation treatment is an effective, although it is simple methods of physiotherapy [51].

Massage therapy: Involves working and acting on the body with pressure tension, motion, or vibration, done manually or with mechanical aid [52]. Massage offers physical benefits, such as increased blood and parasympathetic circulation, and improved joint movement, along with psychological benefits, such as relaxation, daily activity promotion, and pain relief [53]. Massage may produce pain relief by pressure stimuli from massage competing with pain stimuli to reach the brain first, thereby, closing the gate to pain, or by restoring sleep and inhibiting the release of Substance P, which is associated with pain [54]. A reduction in muscle rigidity and spasm also may be critical in SCD due to the role of spasms in SCD pain .Tiffany Field and her colleagues at the Touch Institute have extensively examined the positive effects of massage therapy on emotional adjustment (e.g., depression, anxiety), pain responses, activities of daily living (e.g., school attendance, sleeping habits), and stress hormones levels (e.g., cortisol, epinephrine) [55]. Lemanek, et al. studied a randomized controlled trial investigated the short-term effects of massage therapy on youth with SCD and their parents. Youth in this group showed higher levels of functional status, and lower levels of depression, anxiety, and pain [56].

Acupuncture therapy: It has been practiced for thousands of years in China [57]. Most recently, a meta-analysis found acupuncture to be an effective treatment for chronic pain. Acupuncture may mediate various pathways in the CNS between afferent impulses from pain regions and impulses from acupoints to alleviate pain. Existing evidence also suggests that diverse signal molecules contribute to mediating acupuncture analgesia [58], such as opioid peptides, 5-hydroxytryptamine, and cholecystokinin octapeptide and increase endogenous pain modulating substances, such as beta-endorphins, magnesium, and CSF met-enkephalin [59,60]. To date, there are limited studies on the usefulness of acupuncture for SCD. Patients who are facing significant distress due to their pain and are not being provided adequate relief with pharmacologic therapy alone, acupuncture could potentially serve as adjuvant therapy for pain management [61].

Aquatic rehabilitation: Aquatic rehabilitation program found statistically significant reduction in pain [62-64]. It is beneficial in the management of patients with musculoskeletal problems, neuropathic and pain problems. In addition, the margin of therapeutic safety is wider than that of almost any other treatment milieu [65]. Warm water facilitates muscle relaxation and increases peripheral circulation and stimulates body awareness, balance, and trunk stability; the reduction of gravitational forces results in decreased pain sensitivity. Improvement of patient morale and confidence can be established by providing a positive media to function. Aquatic Rehabilitation may be prescribed specifically for cases with chronic and longstanding pain as in SCD [66]. The aquatic rehabilitation program is used for patients with sickle cell anemia. The treatment included warm water exercises, stretching, aerobic exercise, and relaxation. The patient experienced a significant decrease in pain, significant increase in the strength of respiratory muscles, and improved quality of life. It is conclude that aquatic rehabilitation can be used to improve the clinical condition of SCD patients [67].

Hydroxyurea therapy: The only drug currently approved by the US Food and Drug Administration (FDA) for the treatment of SCD. Long-term HU is currently the accepted treatment for frequent and severe pain. $\mathrm{HU}$ is a potentially leukemogenic and carcinogenic agent [68]. These increases total and fetal hemoglobin in SCD. The increase in fetal hemoglobin retards gelation and sickling of RBCs. $\mathrm{HU}$ also reduces levels of circulating leukocytes, which decreases the adherence of neutrophils to the vascular endothelium. In turn, these effects reduce the incidence of pain episodes [69] and other complications [70]. Studies reviewed herein provide increasing support of efficacy, effectiveness, and safety in both children and adults. In a meta-analysis of the literature through 2007, Strouse, et al. studied found that in children fetal the hemoglobin levels increased from $5-10 \%$ to $15-20 \%$; hemoglobin concentration increased modestly (approximately $1 \mathrm{~g} / \mathrm{L}$ ) but significantly; hospitalizations decreased by $56-87 \%$; and the frequency of pain crisis decreased [71]. Children studied by a cooperative group remained on hydroxyurea for more than a year with only minor adverse effects, but potential complications [72].

Vitamin D: Pain in SCD is the earliest, clinical manifestation and the major cause by vaso-occlusion crises [73]. Vitamin D deficiency (VDD) is quite common in SCD. VDD can cause chronic pain, compression fractures, and muscle weakness [74]. Thus, VDD condition are associated with an increased risk of low bone mineral density (BMD). Bone integrity in SCD affected by VDD and bone vasculature abnormalities which could lead to osteopenia, osteoporosis and osteonecrosis [75]. VDD affects 33\%$78 \%$ of children and $60-100 \%$ of adults with SCD [76]. Research has shown that vitamin $\mathrm{D}$ exerts anatomic, hormonal, neurological, and immunological influences on pain manifestation, thereby potentially playing a big role in the etiology and maintenance of chronic pain states and associated comorbidities [77]. It appears there is a substantial overlap between the symptoms of chronic pain seen in SCD and VDD.

In both conditions, pain is commonly localized to the lower spine, pelvis and extremity bones and described as a dull, aching pain exacerbated by activity and weight bearing [78]. The combination of vitamin $\mathrm{D}$ and calcium supplement are the major agents in treating low BMD due to osteonecrosis in general population even including SCD patient as there is no restrictions in using such agents in SCD patients $[79,80]$. 
Herbs therapy: Niprisan has passed phases IIA and IIB, and is widely used in Nigeria, and is known and popular in India and the USA. The US FDA has determined there is sufficient safety and efficacy data for NIPRISAN to start Phase III clinical trial. The US FDA Botanical Review Team (BRT) suggested a simpler formulation of NIPRISAN, development of a chemical fingerprint for the formulation using LC/ MS and elucidation of some of the anti-sickling compounds would improve standardization and increase the probability of obtaining FDA marketing approval [81]. This method may include the use of herbs that can prevent crisis and relieve chronic pain. It is proved that use of prickly ash bark and ginkgo bilboa reduces the risk of crisis up to $75 \%[82,83]$. Traditional Herbal Approaches to SCD in Nigeria are grains of paradise Sorghum bicolor, Pterocarpus osun are used in various health conditions, including SCD $[84,85]$.

Hypnosis therapy: The effects of these techniques on pain control, quality of life, and health care utilization were inconsistent, perhaps because of inadequate study designs (e.g., a lack of suitable control groups and non-standardized scripts) [86]. Evidence exists supporting the efficacy of hypnotic analgesia in a variety of experimental [87], and clinical settings, including pain associated with medical or surgical procedures [88]. Gil and colleagues demonstrated a direct correlation between daily use of pain-coping skills and less major health care contacts. Thus, cognitive measures that influence attitudes and improve pain-coping skills appear to have a significant impact on sleep, functional outcomes such as work and school attendance, use of analgesics, and major health care utilization. Since hypnosis is a cognitive-behavioral strategy that has been shown to have a powerful effect on pain management in a number of settings [89]. A study by Rainville and colleagues (2002) using Positron Emission Tomography (PET) provides supportive evidence that distinct brain changes occur during hypnosis particularly in the anterior cingulate cortex, the thalamus, and the pontomesencephalic brainstem during the production of hypnotic states [90].

Blood exchange transfusion: Red cell exchange transfusions remain an effective but possibly underutilized therapy in the acute and chronic treatment of SCD. In a red cell exchange, the patient's red cells are removed and replaced by exogenous normal red cells. The exchange transfusion removes the sickle cells from participating in new vaso-occlusive events, pain, reduces hemolytic complications, and provides added oxygen carrying capacity while decreasing the blood viscosity. Red cell exchange may also be useful when there is a need for chronic maintenance of low Hb levels. There are multiple indications for keeping $\mathrm{HbS}$ low, the best documented of which are primary and secondary stroke prevention and reduction of severe pain $[83,91]$. Other indications with less supporting data include elements of the triad of pulmonary hypertension, priapism and leg ulcers associated with red cell hemolysis [92].

\section{Future trend}

Anti-adhesive agents: Anti-adhesive agents-i.e., agents that impair adhesion in sickle cell disease. These include several classes of drugs/ agents such as anti-selectin, blockers of cell-cell, cell-protein and or protein-protein adhesion. Some of the anti-selectin agents are SelG1-a humanised monoclonal antibody antibodydirected against P-selectin called SelG1. A phase I clinical study showed that SelG1 was safe and well tolerated in healthy males and females. There were no infection-related adverse events, alterations in coagulation test results, bleeding, or formation of specific antibodies against SelG1. Pharmacodynamic analysis showed that a single $5 \mathrm{mg} / \mathrm{kg}$ dose of SelG1 was sufficient to block P-selectin activity for at least 28 days. The current phase II trial is testing the use of SelG1 as preventive therapy for vaso-occlusive complications of SCD, specifically acute painful episodes. SelG1 is being tested as monthly infusions at two dose levels $(5 \mathrm{mg} / \mathrm{kg}$ and $2.5 \mathrm{mg} / \mathrm{kg})$. Potential adverse effects of P-selectin inhibition include bleeding, the possibility of infection because $\mathrm{P}$-selectin is a mediator of neutrophil adhesion to the vascular endothelium [93].

Anti-platelet agents: Treatment of either acute or chronic clinical manifestation of SCD is still limited due to the small and relative lowquality design of the studies [94] and few reports on the use of such agents in SCD. However, most of these studies did not correlate with in vivo effect of the drugs on platelet activation with specific clinical endpoints [91]. Recent reports suggest that antiplatelet agents, particularly when administered at doses sufficient to inhibit platelet activation may be beneficial in preventing or treating vaso-occlusive complications in patients with SCD $[95,91]$.

Anti-coagulant treatment: Treatment with heparin, has been considered as an additional therapeutic approach to block sickle cell adhesion to endothelial cells through the P-selectin pathway [96], or binding to TSP that can mediate the interactions between sickle erythrocytes and the vascular endothelial surface. A doubleblind randomized trial with tinzaparin in SCD patients during acute vaso-occlusive events documented a reduction of their severity and duration [97]. Studies with low dose of warfarin or acenocoumarol were reported to slightly reduce the frequency of acute pain events with decreased thrombin generation and fibrinolysis, however without reaching a significant clinical amelioration [98].

Calpain 1 therapy: In the Berkeley sickle mice, mast cell activation contributes to neurogenic inflammation, chronic pain, and Hypoxia/Reoxygenation (H/R)-evoked hyperalgesia, which were ameliorated upon treatment with mast cell inhibitor imatinib, and cannabinoids as well as nociception receptor ligand AT200 $[99,100]$. Systemic deletion of calpain-1 in Townes sickle mice ameliorated chronic pain behaviors including mechanical, heat, cold, and deep tissue/musculoskeletal hyperalgesia. The ultimate goal of any sickle cell therapy is the reduction of chronic pain and episodes of acute pain crises in patients with SCD [101]. In rat models of spinal nerve injury, inhibition of calpain-1 reduced neuropathic pain [102]. Thus, evaluated whether experimental sickle mice SSCKO would show a reduction in pain behaviors that have been previously characterized in the Berkeley and Townes sickle mice [99]. The chronic thermal and deep tissue hyperalgesia are completely ameliorated by the deletion of calpain-1 gene in SS mice. Thus, calpain-1 may contribute to the regulation of chronic hyperalgesia in SCD [101].

Gene therapy treatment: Has long been proposed as a potential cure for SCD [103]. The permanent delivery of a corrective or antisickling gene cassette into long-term, repopulating hematopoietic stem cell could allow for the production of corrected RBCs for the long life of the patient. In order for gene therapy for SCD to become a reality, 2 main objectives must be achieved: (1) safe and efficient gene transfer or correction of long-term repopulating hematopoietic stem 
cell and (2) high-level, appropriately regulated, stable gene expression. With current progress at the laboratories and in the clinical work, these goals now appear within reach. The long path to the clinic for SCD gene therapies has been paved by landmark discoveries that have provided important insights into the developmental regulation of the $\beta$-globin gene cluster [104].

\section{Conclusion}

Pain in SCD is multifactorial, nociceptive and neuropathic. The nociceptive pain which seems the more common type of pain in SCD, could happen due to vision, hearing, tasting, and feelings without nerve damage. Although there is no guideline to treat the sickle cell anemia, the non convenential methods in pain relief as the reassurance, hand massage; vibration massage, transcutaneous electrical nerve stimulation, psychological treatment and social care should be all applied to avoid using the opioids which could drive the sickle cell patients to be opiods dependent.

\section{Acknowledgment}

The sickle cell disease Project funded "Partially" by Kuwait Foundation for the advancement of science(KFAS) under code: P116 - 13MM-01. Our thankful to the sickle cell Kuwaiti group in its cooperative work in this review.

\section{References}

1. National Heart, Lung, and Blood Institute. What Are the Signs and Symptoms of Sickle Cell Disease? 2016.

2. Yawn BP, Buchanan GR, Afenyi-Annan AN, Ballas SK, Hassell KL, James $\mathrm{AH}$, et al. Management of sickle cell disease: summary of the 2014 evidencebased report by expert panel members. JAMA. 2014; 312: 1033-1048.

3. Priscilla. Antioxidant Status of Sickle Cell Disease Children with and without Malaria at the Korle-Bu Teaching Hospital. Dspace Repository, Ghana. 2013

4. Ballas SK. Sickle cell pain. Progress in pain research and management, Vol. II. Seattle (WA): IASP Press; 1998

5. Benjamin LJ, Dampier CD, Jacox A. Guideline for the management of acute and chronic pain in sickle cell disease. Glenview (IL). American Pain Society. 1999

6. Ballas SK. Pain management of sickle cell disease. Hematol Oncol Clin North Am. 2005; 19: 785-802.

7. Dampier C, Ely B, Brodecki D, Coleman C, Aertker L, Sendecki JA, et al. Pain characteristics and age-related pain trajectories in infants and young children with sickle cell disease. Pediatr Blood Cancer. 2014; 61: 291-296.

8. Smith WR, Penberthy LT, Bovbjerg VE, McClish DK, Roberts JD, Dahman B, et al. Daily assessment of pain in adults with sickle cell disease. Ann Intern Med. 2008; 148: 94-101.

9. Sil S, Cohen LL, Dampier C. Psychosocial and Functional Outcomes in Youth With Chronic Sickle Cell Pain. Clin J Pain. 2016; 32: 527-533.

10. Lutz B, Meiler SE, Bekker A, Tao YX. Updated Mechanisms of Sickle Cell Disease-Associated Chronic pain. Transl Perioper Pain Med. 2015; 2: 8-17.

11. Anupam Aich, Alvin J Beitz and Kalpna Gupta. Mechanisms of Pain in Sickle Cell Disease.

12. Basbaum Al, Jessell T. The Perception of Pain. In: Kandel ER, Schwartz $\mathrm{J}$, Jessell T, editors. Principles of Neuroscience. New York: Appleton and Lange; 2000; 472-491.

13. Santiago, Lovely Trasmonte, April Allison Tubo, Maverick. Pain Management 2013.

14. Fields HL. Pain. New York: McGraw-Hill; 1987.
15. Garland EL. Pain processing in the human nervous system: a selective review of nociceptive and biobehavioral pathways. Prim Care. 2012; 39: 561-571.

16. Waun Ki Hong, Robert C Bast, Wiliam N Hait, Donald W Kufe, Raphael E Pollock, Ralph R Weichselbum, James F Holland, Emil Frei III. American Association. Holland-Frei Cancer Medicine. 2010; 8.

17. Sengupta JN, Su X, Gebhart GF. Kappa, but not mu or delta, opioids attenuate responses to distention of afferent fibers innervating the rat colon. Gastroenterology. 1996; 111: 968-980.

18. Burton MB, Gebhart GF. Effects of kappa-opioid receptor agonists on responses to colorectal distension in rats with and without acute colonic inflammation. J Pharmacol Exp Ther. 1998; 285: 707-715.

19. Brandow AM, Farley RA, Panepinto JA. Neuropathic pain in patients with sickle cell disease. Pediatr Blood Cancer. 2014; 61: 512-517.

20. Sethna NF, Meier PM, Zurakowski D, Berde CB. Cutaneous sensory abnormalities in children and adolescents with complex regional pain syndromes. Pain. 2007; 131: 153-161.

21. Platt OS, Thorington BD, Brambilla DJ, Milner PF, Rosse WF, Vichinsky E, et al. Pain in sickle cell disease. Rates and risk factors. N Engl J Med. 1991; 325: 11-16.

22. Ballas SK, Lusardi M. Hospital readmission for adult acute sickle cell painful episodes: frequency, etiology, and prognostic significance. Am J Hematol. 2005; 79: 17-25.

23. Smith WR, Penberthy LT, Bovbjerg VE, McClish DK, Roberts JD, Dahman $B$, et al. Daily assessment of pain in adults with sickle cell disease. Ann Intern Med. 2008; 148: 94-101.

24. Wilkie DJ, Molokie R, Boyd-Seal D, Suarez ML, Kim YO, Zong S, et al. Patient-reported outcomes: descriptors of nociceptive and neuropathic pain and barriers to effective pain management in adult outpatients with sickle cell disease. J Natl Med Assoc. 2010; 102: 18-27.

25. Hillery CA, Kerstein PC, Vilceanu D, Barabas ME, Retherford D, Brandow $\mathrm{AM}$, et al. Transient receptor potential vanilloid 1 mediates pain in mice with severe sickle cell disease. Blood. 2011; 118: 3376-3383.

26. Torrance N, Smith BH, Bennett MI, Lee AJ. The epidemiology of chronic pain of predominantly neuropathic origin. Results from a general population survey. J Pain. 2006; 7: 281-289.

27. Wampold BE. The Great Psychotherapy Debate: Models, Methods, and Findings. L. Erlbaum Associates, Routledge. 2001.

28. Chaparro LE, Wiffen PJ, Moore RA, Gilron I. Combination pharmacotherapy for the treatment of neuropathic pain in adults. Cochrane Database Syst Rev. 2012.

29. Svedlund J, Sjödin I, Ottosson JO, Dotevall G. Controlled study of psychotherapy in irritable bowel syndrome. Lancet. 1983; 2: 589-592.

30. Ilesanmi OO. Gender Differences in Sickle Cell Crises: Implications for Genetic Counselling and Psychotherapy. J Psychol Psychother. 2014; 4: 215-220.

31. Airaksinen O, Brox JI, Cedraschi C, Hildebrandt J, Klaber-Moffett J, Kovacs F, et al. COST B13 Working Group on Guidelines for Chronic Low Back Pain. Chapter 4. European guidelines for the management of chronic nonspecific low back pain. Eur Spine J. 2006; 15: S192-300.

32. Williams DA, Carey M. You Really Need To Relax: Effective Methods UMHS. 2003.

33. Sluka KA, Walsh D. Transcutaneous electrical nerve stimulation: basic science mechanisms and clinical effectiveness. J Pain. 2003; 4: 109-121.

34. Kandel ER, Schwartz JH, Jessell TM, Siegelbaum SA, Hudspeth AJ. Principles of Neural Science, McGraw-Hill, New York, NY, USA, 4th edition, 2000.

35. Barker R, Lang T, Steinlechner B, Mora B, Heigel P, Gauss N, et al. Transcutaneous electrical nerve stimulation as prehospital emergency interventional care: treating acute pelvic pain in young women. Neuromodulation. 2006; 9: 136-142. 
36. Lang T, Barker R, Steinlechner B, Gustorff B, Puskas T, Gore O, et al. TENS relieves acute posttraumatic hip pain during emergency transport. J Trauma. 2007; 62: 184-188.

37. Sok Cheon Pak, Peter S. Micalos, Sonja J. Maria, and Bill Lord. Nonpharmacological Interventions for Pain Management in Paramedicine and the Emergency Setting: A Review of the Literature. Evidence-Based Complementary and Alternative Medicine. 2015.

38. Wang WC, George SL, Wilimas JA. Transcutaneous electrical nerve stimulation treatment of sickle cell pain crises. Acta Haematol. 1988; 80 99-102.

39. David S Moore, George P. McCabe, William M Duckworth. Practice of Business Statistics: Using Data for Decisions 2nd Edition. ISBN 9781490250151. 2017.

40. Laska E, Sunshine A. Anticipation of analgesia. A placebo effect. Headache. 1973; 13: 1-11.

41. Gottlieb Scott. The FDA Wants You for Sham Surgery. Wall Street Journal. 2015

42. Lanotte M, Lopiano L, Torre E, Bergamasco B, Colloca L, Benedetti F. Expectation enhances autonomic responses to stimulation of the human subthalamic limbic region. Brain Behav Immun. 2005; 19: 500-509.

43. Benedetti F, Mayberg HS, Wager TD, Stohler CS, Zubieta JK. Neurobiological Mechanisms of the Placebo Effect. J Neurosci. 2005; 25; 10390-10402.

44. Lieberman MD, Jarcho JM, Berman S, Naliboff BD, Suyenobu BY Mandelkern $\mathrm{M}$, et al. The neural correlates of placebo effects: a disruption account. Neuroimage. 2004; 22: 447-455.

45. The Placebo Phenomenon. 14 December 2012

46. Ernst E, Resch KL. Concept of true and perceived placebo effects. BMJ. 1995; 311: 551-553.

47. Cardinale $\mathrm{M}$, Wakeling $\mathrm{J}$. Whole body vibration exercise: are vibrations good for you? Br J Sports Med. 2005; 39: 585-589.

48. Bosco C, Colli R, Introini E, Cardinale M, Tsarpela O, Madella A, et al. Adaptive responses of human skeletal muscle to vibration exposure. Clin Physiol. 1999; 19: 183-187.

49. Rittweger J. Vibration as an exercise modality: how it may work, and what its potential might be. Eur J Appl Physiol. 2010; 108: 877-904.

50. Susan Agrawal. Vibration for Pain Control and Calming. Complex Child E-Magazine. 2009.

51. Jasper Sidhu. Vibration therapy for circulation. Copyright $2012-2015$ by Vibration Exercise.

52. Heitzer E1, Seidl H, Bambach I, Schmidbauer U, Cerroni L, Wolf $P$ Infrequent p53 gene mutation but UV gradient-like p53 protein positivity in keloids. Exp Dermatol. 2012; 21: 277-280.

53. Fritz, S. Mosby's fundamentals of therapeutic massage. St Louis: Mosby 2000 .

54. Bodhise PB1, Dejoie M, Brandon Z, Simpkins S, Ballas SK. Nonpharmacologic management of sickle cell pain. Hematology. 2004; 9: 235237.

55. Field, T. Touch. Cambridge, Massachusetts: The MIT Press. 2001.

56. Lemanek KL, Ranalli M, Lukens C. A Randomized Controlled Trial of Massage Therapy in Children with Sickle Cell Disease. J Pediatr Psychol 2009; 34: 1091-1096.

57. Sierpina VS, Frenkel MA. Acupuncture: a clinical review. South Med J. 2005 98: 330-337.

58. Zhao ZQ. Neural mechanism underlying acupuncture analgesia. Prog Neurobiol. 2008; 85: 355-375.

59. Zhao $\mathrm{CH}$, Stillman MJ, Rozen TD. Traditional and evidence-based acupuncture in headache management: theory, mechanism, and practice.
Headache $2005 ; 45: 716-730$.

60. Sherman KJ, Cherkin DC, Eisenberg DM, Erro J, Hrbek A, Deyo RA. The Practice of Acupuncture: Who Are the Providers and What Do They Do? Ann Fam Med. 2005; 3: 151-158.

61. Lu K, Cheng MC, Ge X, Berger A, Xu D, Kato GJ, et al. A retrospective review of acupuncture use for the treatment of pain in sickle cell disease patients: Descriptive analysis from a single institution. Clin J Pain. 2014 30: 825-830.

62. Wall PD, Melzack R, editors. Textbook of pain. 4th edition. New York: Churchill Livingstone; 1999.

63. Bodhise PB, Dejoie M, Brandon Z, Simpkins S, Ballas SK. Non-pharmacologic management of sickle cell pain. Hematology. 2004; 9: 235-837.

64. Tinti G, Somera R Jr, Valente FM, Domingos CR. Benefits of kinesiotherapy and aquatic rehabilitation on sickle cell anemia. A case report. Genet $\mathrm{Mol}$ Res. 2010; 9: 360-364.

65. Becker BE. Aquatic therapy: scientific foundations and clinical rehabilitation applications. PM R. 2009; 1: 859-872.

66. American Academy of Physical Medicine and Rehabilitation. 2009; 1: 859872.

67. AQUAHAB Physical Therapy 2017.

68. Tinti G, Somera R Jr, Valente FM, Domingos CR. Benefits of kinesiotherapy and aquatic rehabilitation on sickle cell anemia. Genet and Mol Res. 2010; 9: 360-364.

69. McGann PT, Ware RE. Hydroxyurea therapy for sickle cell anemia. Expert Opin Drug Saf. 2015; 14: 1749-1758.

70. Heeney MM, Ware RE. Hydroxyurea for children with sickle cell disease. Pediatr Clin North Am. 2008; 55: 483-501.

71. Brawley OW, Cornelius LJ, Edwards LR, Gamble VN, Green BL, Inturris C, et al. National Institutes of Health Consensus Development Conference statement: hydroxyurea treatment for sickle cell disease. Ann Intern Med. 2008; 148: 932-938

72. Strouse JJ, Lanzkron S, Beach MC, Haywood C, Park H, Witkop C, et al. Hydroxyurea for sickle cell disease: a systematic review for efficacy and toxicity in children. Pediatrics. 2008; 122: 1332-1342.

73. Joseph E Maakaron, Ali T Taher. Sickle Cell Anemia Treatment \& Management. by WebMD LLC. 2016.

74. Desai P, Dejoie-Brewer M, Ballas SK. Deafness and sickle cell disease: three case reports and review of the literature. J Clin Med Res. 2015; 7 : 189-192.

75. Ifeyinwa Osunkwo. Vitamin D for Sickle Cell (SCD Vitamin D). ClinicalTrials. gov Identifier: NCT01331148.

76. Serarslan Y, Kalaci A, Ozkan C, DoÄŸramaci Y, Cokluk C, Yanat AN. Morphometry of the thoracolumbar vertebrae in sickle cell disease. $\mathrm{J}$ Clin Neurosci. 2010; 17: 182-186.

77. Winters AC, Kethman W, Kruse-Jarres R, Kanter J. Vitamin D Insufficiency is a Frequent Finding in Pediatric and Adult Patients with Sickle Cell Disease and Correlates with Markers of Cell Turnover. J Nutr Disorders Ther. 2014 4: 140.

78. Holick MF. Vitamin D deficiency. N Engl J Med. 2007; 357: 266-281.

79. National Osteoporosis Foundation. Osteoporosis Clinical Updates. 2014.

80. Al-Jafar H, Leena M A, Al-Shemmeri J, Al-Ali N, Al-Enizi F. Could Denosumab Support Bone Integrity in Sickle Cell Disease. J Hematol Thromb. 2015; 1: 4.

81. Ameh SJ, Tarfa FD, Ebeshi BU. Traditional herbal management of sickle cell anemia: lessons from Nigeria. Anemia. 2012; 2012: 607436.

82. PRICKLY ASH BARK (Zanthoxylum species), An mhtm document by Dr. Tillotson of Tillotson Institute of Natural Health, 2011.

83. Herbs for sickle cell anemia. 
84. Ameh SJO, Obodozie US, Inyang, Abubakar MS, Garba M. Climbing black pepper (Piper guineense) seeds asan antisickling remedy, in Nuts \& Seeds in Health and Disease Prevention, Preedy VR, Watson RR, Patel VB, Eds. 333-343, Academic Press, London, UK, 1st edition, 2011.

85. Sunday J, Ameh, Obiageri O, Obodozie, Uford S, Inyang, Mujitaba S Abubakar, Magaji Garba. Herbal clinical trials-historical development and application in the 21st Century. Pharmacologia. 2012; 3: 121-131.

86. Wallen GR1, Middleton KR1, Ames N1, Brooks AT1, Handel D2. Randomized trial of hypnosis as a pain and symptom management strategy in adults with sickle cell disease. Integr Med Insights. 2014; 9: 25-33.

87. Dillworth T, Jensen MP. The Role of Suggestions in Hypnosis for Chronic Pain: A Review of the Literature. Open Pain J. 2010; 3: 39-51.

88. Hilgard ER, LeBaron S. Hypnotherapy of Pain in Children with Cancer. Los Altos, CA: William Kaufmann; 1984

89. Gil KM, Carson JW, Sedway JA, Porter LS, Wilson-Schaeffer JJ, Orringer E. Follow-up of coping skills training in adults with sickle cell disease: analysis of daily pain and coping practice diaries. Health Psychol. 2000; 19: 85-90.

90. Rainville P, Hofbauer RK, Bushnell MC, Duncan GH, Price DD. Hypnosis modulates activity in brain structures involved in the regulation of consciousness. J Cogn Neurosci. 2002; 14: 887-901.

91. Swerdlow PS1. Red cell exchange in sickle cell disease. Hematology Am Soc Hematol Educ Program. 2006.

92. Kato GJ, McGowan V, Machado RF, Little JA, Taylor J 6th, Morris CR, et al. Lactate dehydrogenase as a biomarker of hemolysis-associated nitric oxide resistance, priapism, leg ulceration, pulmonary hypertension, and death in patients with sickle cell disease. Blood. 2006; 107: 2279-2285.

93. Charles T. Quinn. Anti-Adhesive Therapy for Sickle Cell Disease. National Heart, Lung, and Blood Institute (NHLBI). American Society of Hematology. 2014; 11.

94. Adam SS, Key NS, Greenberg CS. D-dimer antigen: current concepts and future prospects. Blood. 2009; 113: 2878-2887.
95. Lee SP, Ataga KI, Orringer EP, Phillips DR, Parise LV. Biologically active CD40 ligand is elevated in sickle cell anemia: potential role for plateletmediated inflammation. Arterioscler Thromb Vasc Biol. 2006; 26: 1626-1631.

96. Kato GJ, Martyr S, Blackwelder WC, Nichols JS, Coles WA, Hunter LA, et al. Levels of soluble endothelium-derived adhesion molecules in patients with sickle cell disease are associated with pulmonary hypertension, organ dysfunction, and mortality. Br J Haematol. 2005; 130: 943-953.

97. Gayen Betal S, Setty B N. Phosphatidylserine-positive erythrocytes bind to immobilized and soluble thrombospondin-1 via its heparin-binding domain Transl Res 2008; 152: 165-17.

98. Schnog JJ, Kremer Hovinga JA, Krieg S, Akin S, Lämmle B, Brandjes DP et al. ADAMTS13 activity in sickle cell disease. Am J Hematol. 2006; 81: 492-498.

99. Vincent L, Vang D, Nguyen J, Gupta M, Luk K, Ericson ME, et al. Mast cell activation contributes to sickle cell pathobiology and pain in mice. Blood. 2013; 122: 1853-1862.

100. Vincent L, Vang D, Nguyen J, Benson B, Lei J, Gupta K. Cannabinoid receptor-specific mechanisms to ameliorate pain in sickle cell anemia via inhibition of mast cell activation and neurogenic inflammation. Haematologica. 2016; 101: 566-577.

101. Nwankwo JO, Lei J, Xu J, Rivera A, Gupta AH. Genetic inactivation of calpain-1 attenuates pain sensitivity in a humanized mouse model of sickle cell disease. Haematologica . 2016; 101: e397-e400. Epub 2016.

102. Zhou HY, Chen SR, Byun HS, Chen H, Li L, Han HD, et al. N-methyl-Daspartate receptor-and calpain-mediated proteolytic cleavage of $\mathrm{K}+-\mathrm{Cl}$ cotransporter-2 impairs spinal chloride homeostasis in neuropathic pain. J Biol Chem. 2012; 287: 33853-33864.

103. Bank A, Markowitz D, Lerner N. Gene transfer. A potential approach to gene therapy for sickle cell disease. Ann N Y Acad Sci. 1989; 565: 37-343.

104. Hoban MD, Orkin SH, Bauer DE. Genetic treatment of a molecular disorder: gene therapy approaches to sickle cell disease. Blood 2016; 127: 839-848.
Ann Hematol Oncol - Volume 4 Issue 7 - 2017

ISSN : 2375-7965 | www.austinpublishinggroup.com

Al-Jafar et al. (C) All rights are reserved
Citation: Al-Jafar H, Al-Feeli A and Alozairi A. Non-Conventional Pain Management for Sickle Cell Disease. Ann Hematol Oncol. 2017; 4(7): 1161 